\title{
A digital map of folk songs from the collection of Adolf Dygacz
}

\author{
Adolf Dygacz. Historia muzycznej podróży (Adolf Dygacz: The history of \\ the musical journey). \\ Website created by Agata Krajewska: www.adolfdygacz.pl
}

DOI: 10.12775/LL.1.2021.010 | CC BY-ND 3.0 PL

Digitization of archival folklore collections has become extremely popular in the last decade. Thanks to that, materials with limited access gain a wider group of recipients, and the previously disorderly resources are described and systematized. An example of such activities is the digitization of Oskar Kolberg's Dzieła wszystkie (Collected works), carried out by the National Library on the occasion marking the Kolberg Year (2014). These collections were made available in the Polona Digital Library in March 2015. In many cases, music collections are also digitized. In 2018, The Upper Silesian Ethnographic Park in Chorzów launched a multi-stage project entitled „The digitization of the collections of Adolf Dygacz” (Krajewska 2020: 75). The aim of this project is to prepare documents related to the field activities of the aforementioned ethnomusicologist, including manuscripts with music notations of songs, typescripts with texts and audio recordings from reel-to-reel tapes (Krajewska 2020: 76). The author of the project reviewed here, a researcher associated with the University of Silesia in Katowice - Agata Krajewska - used these materials in her work. The website called Adolf Dygacz: The history of the musical journey is the result of the creative scholarship of the Minister of Culture and National Heritage, which she received in 2020. The project consisted of the creation of an interactive map of the places where Dygacz had recorded folk songs. As the author herself recalls, her main goal was to outline the scope of his research, which took place in the 50-70s of the 2oth century, in unfavorable conditions, due to the fact that the researcher was struggling with numerous logistical and technical problems at that time. Krajewska's task was not easy also due to the fact that Adolf Dygacz was a scientist known for his diligence. 
Dygacz was born on July 23, 1914 in Droniowice near Lubliniec. Although he started collecting folklore materials before the 1940s, he accumulated most of them in the period between 1940-1970 (Krajewska 2020: 75). The researcher devoted his life to music and was extremely versatile in this respect - he dealt with ethnomusicology, he was a music journalist (Wójcik 2015: 27), but also a respected educator and promoter of numerous master's and doctoral dissertations (Hojka 2019: 225). He worked at the University of Wrocław and the University of Silesia in Katowice, he was a member of numerous scientific organizations, including the Polish Ethnological Society. He died on April 5, 2004 in Katowice. The archives contain approximately 3000 recordings, including many workers' songs, which constituted his main interest. The concept of an interactive map created by Agata Krajewska seems to be an interesting way to organize the numerous archival resources.

In the case of printed texts, the visual issues related to their publication are usually not paid attention to. However, it is worth devoting a few sentences to this issue in the context of the website discussed here. As part of the project, a clear and aesthetic graphical interface was constructed. On the home page there are hyperlinks to the most important elements: Dygacz's biography, the maps of his ethnographic journey and the section with individual songs. These can also be accessed by going to the individual tabs on the top bar of the page, where there is also a link to basic information about the project, supplemented with photographs from the researcher's private archives. The information obtained during a conversation with his wife, Janina Dygacz, was used by Krajewska to create a section presenting an extensive biography of the musicologist. It includes a description of his youth, the period of the Second World War, research and teaching activities, and his later life. The fact that Dygacz's research is known internationally was also taken into account - he belonged to the International Center for Research on Workers' Song „in which [...] he was a representative of Poland, which enabled him to cooperate with foreign folklorists from twelve countries". Information on his private life and scholarly activities has been enriched with a short bibliography and the aforesaid photographs.

The methodology of his field work is also briefly presented on the page, as well as the ordination of folk songs adopted by him, which he divided into:

1. ritual songs - connected with the action of the rite, performed at a specific time and in specific circumstances;

2. professional songs - about the profession or work, duties and everyday life of employees of mines, steel mills, raftsmen, farmers and representatives of other professions;

3. common songs - sung by the local community in various circumstances, accompanying fun, but also death - in times of tragedy, concerning important historical events.

Krajewska does not forget to outline the technical context of the research - she provides information on sound recorders that the researcher used in the field, as well as on the way in which he recorded the lyrics.

The most important element of the website is the section with the map of Poland, where Dygacz's field research sites have been marked. There are about a hundred locations here, and usually one song is assigned to each of them. Krajewska, 
guided by the criterion of the place of recording (but also taking into account the "readability and availability of recordings"), selected about a hundred songs from nearly 3 ooo known recordings of the Silesian folklorist, which seems to be a rather modest attempt, presenting only a fraction of this extensive collection. The main goal of the project, however, was to show the journey that Dygacz had made while registering folklore material; therefore, limiting the selection to the most important places, according to the author, was a logical approach, conducive to map readability. It is also not surprising that the recordings which had not survived the test of time were omitted - their reconstruction was probably impossible or would require more time. In the description of the project, however, Krajewska indicates that in the later stages of the work, the website will be supplemented with musical transcriptions of selected songs. So, the project remains open, and hopefully the map will be supplemented with more locations and songs in the future. Currently, the most important information has been assigned to the marked places - namely the name of the place, the title of the song and a link that sends the user to the "Multimedia" section.

In the "Multimedia" section, on the left there is a list of all the songs marked on the map, and on the right there are illustrations from the Dygacz archive, including a sample flashcard, manuscript with music notation and typescript with the text of a song. The list is arranged in a non-alphabetical manner, therefore in order to efficiently navigate through the presented materials the search engine built into the website proves indispensable, allowing the user to search for items according to the place of their recording and incipit. The pages of individual songs contain transcriptions of texts, sound files with field recordings and basic information about the date of the recording and the performer. The songs also have short descriptions; although they are usually laconic, they can be a good starting point for further research and searching for other variants. The author herself also adds information about the number of songs performed by a given informant or informants (songs include instrumental pieces performed by ensembles and sung by more than one person). The presentation of other variants of the song is one of the possible directions of expansion of the discussed website. The project could also be enriched with a more advanced search engine, enabling full-text search and allowing for categories such as song genre or keywords. Although the latter are assigned to each piece and refer to the ordination of songs adopted by Dygacz, there is no possibility of searching by them. Despite these shortcomings, the way of presenting the multimedia is well thought out and the whole thing is easy to navigate.

Among the materials available on the website, one can find examples of ritual, professional and common songs - the latter are by far the most numerous. Among the professional songs, those related to mining and metallurgy deserve attention; these two sections were treated by Dygacz as separate varieties of musical folklore (Krajewska 2020: 78). It is worth noting that in the case of some works, more extensive information was provided on the context in which they functioned (for example, descriptions of rituals) and on references to Dygacz's personal experiences.

The "Projects/Publications" tab, which contains information on other activities related to the discussed project, also proves to be interesting. There are, among others, links to the description of the above-mentioned digitization project of 
Dygacz's collection implemented by The Upper Silesian Ethnographic Park in Chorzów, information on the educational project "The Sung Tradition", which was aimed at popularizing knowledge about local singing groups (Krajewska took part in it), as well as a link to the researcher's article (Krajewska 2020).

The website Adolf Dygacz: The history of the musical journey created by Agata Krajewska is interesting in many ways. First of all, it allows the visitors to familiarize themselves with the songs recorded by Dygacz in a convenient way. This type of mapping of records of musical folklore also allows for the reconstruction of the scope of field research, while the concept of an open website makes it possible to update and further expand the collection. Summing up, it can be said that despite the lack of a few of the aforementioned technical accommodations and the limited scope of the presented archives, the subject matter of the discussed website is factually and conceptually valuable and can be useful both in further scientific research and in activities in the field of regional education.

\section{REFERENCES}

Hojka, Z. (2019). Adolf Karol Dygacz - etnograf, etnomuzykolog, folklorysta, badacz i znawca kultury Górnego Śląska i Zagłębia Dąbrowskiego. Analecta, 28(1), 217-229.

Krajewska, A. (2020). Digitalizacja archiwów folklorystycznych - kryzys tradycji czy nowe życie w sieci? Przykład zbiorów Adolfa Dygacza. Kwartalnik Młodych Muzykologów UJ, 46, 71-89.

Muzeum (2020). Wirtualne oprowadzanie po wystawie „Życie jako pieśń. Z teki profesora Adolfa Dygacza” [strona internetowa Muzeum „Górnośląski Parku Etnograficzny w Chorzowie”]. Pobrano z: http://muzeumgpe-chorzow.pl/pl/wirtualne-oprowadzanie-po-wystawie-zycie-jako-piesn-z-tekiprofesora-adolfa-dygacza/

Wójcik, A. (2015). Co nieco o publicystyce i społecznej aktywności Adolfa Dygacza. Studia Artystyczne, $3,27-39$. 